\title{
DEVELOPMENT OF NEW WINTER AND SPRING WHEAT VARIETIES IN LATVIA
}

\author{
Vija Strazdiṇa \\ State Stende Cereal Breeding Institute, "Dižzemes", Dižstende, Lībagu pag., Talsu nov., LV-3258, LATVIA \\ vijastrazdina@inbox.Iv
}

Communicated by Isaak Rashal

\begin{abstract}
The newest wheat varieties developed at the State Stende Cereal Breeding Institute are winter wheat 'Fredis' and spring wheat 'Uffo' and 'Robijs'. The winter wheat variety 'Fredis' ('Donskaya Polukarlikovaya'/'Abe'//'Lowrin 24') was developed from 1986 to 2002. The variety has good winter hardiness (7-9 points), earliness (growing period 212-215 days from 1 January), and average yield is $6.0 \mathrm{t} \mathrm{ha}^{-1}$. Grain quality is suitable mostly for food. The variety was registered in the Latvian Plant Catalogue in 2007 and in the Estonian Plant Catalogue in 2011. In the period from 1992 to 2007, the new spring wheat variety 'Uffo' (Sigma/Eta) was created. Variety 'Uffo' is a mid-early variety, with yield potential 6-8 $t \mathrm{ha}^{-1}$, and moderate lodging resistance (5-7 points). Grain quality is suitable for food and feed. The variety 'Uffo' was included in the Latvian Plant Catalogue in 2008 and in the Estonian Plant Catalogue in 2009. The spring wheat variety 'Robijs', obtained from the crossing combinations Dragon/Anninia//Fasan//Fasan by anther culture, was developed at the State Stende Cereal Breeding Institute in collaboration with the Institute of Biology Latvian University from 2000 to 2007. The variety is a middle-early wheat, and is characteriszed by high yield potential $\left(6-8 t h^{-1}\right)$, moderate resistance to lodging (7 points). It has moderate resistance to powdery mildew (3-5 point) and brown rust (10-25\%). The grain quality is suitable for food. The variety was included in the Latvian Plant Catalogue in 2011.
\end{abstract}

Key words: wheat variety, pedigree, yield, grain quality.

\section{INTRODUCTION}

In Latvia winter and spring wheat breeding began in 1922. Since that time, a large-scale collection of winter wheat germplasm has been collected and applied for hybridisation and selection. In each breeding programme, specific collections of material suitable for local conditions were used (Rashal, 2002; Strazdina and Rashal, 2005). Altogether, 29 winter and spring varieties have been developed in Latvia during the wheat breeding history (for details see Strazdina, 2012, this issue). While winter wheat breeding continued in Latvia without large gaps, spring wheat breeding was stopped for about 20 years due to the opinion that wheat produced in Latvia was only suited for feed (Strazdina et al., 2011). The breeding of spring wheat was renewed in 1990. Presently, the breeding of both wheat types are conducted at the State Stende Cereal Breeding Institute

The aim of the current wheat breeding is to create and introduce into commercial production winter and spring wheat varieties adapted both for conventional and organic management, with grain quality corresponding to food industry requirements. Several wheat varieties have been created by traditional breeding methods: hybridisation and subsequent selection. Since 2000, collaboration with the Plant Genetics Laboratory of the Institute of Biology, University of Latvia, has allowed the application of biotechnology methods in wheat breeding programmes.

The aim of this paper is to characterise the newest wheat varieties created at the State Stende Cereal Breeding Institute (CBI): winter wheat 'Fredis', and spring wheat 'Uffo' and 'Robijs'.

\section{MATERIALS AND METHODS}

Pedigrees of varieties. The winter wheat variety 'Fredis' was obtained from the crossing combination 'Donskaya Polukarlikovaya'/'Abe'//'Lowrin 24'. The variety was created at the State Stende Cereal Breeding Institute from 1986 to 2002 (Table 1). The authors are Vija Strazdina, Maija Ceraukste, and Solveiga Malecka. The crossing combination 'Donskaja Polukarlikovaja'/‘Abe' was implemented on field in 1985. The second step was hybridisation with the variety 'Lowrin 24', made in 1986. Since two types of wheat (awnless and awened) were used in the crossing combination, a large diversity of genotypes was obtained in $\mathrm{F}_{3}-\mathrm{F}_{6}$ generations. The hybrid line L-93-130, selected in the $\mathrm{F}_{5}$ generation (Table 1), was both phenotypic and genotypic stable in the next generations and became the progenitor of the variety. 
DEVELOPMENT SCHEME OF WINTER WHEAT 'FREDIS'

\begin{tabular}{|c|c|c|c|c|}
\hline Year & Generation & $\begin{array}{c}\text { Number of } \\
\text { hybrid }\end{array}$ & Pedigree & Breeding stage and place \\
\hline 1985 & $\mathrm{~F}_{0}$ & F-85-19 & Donskaya polukarlikovaya/Abe & $\begin{array}{l}\text { Hybridisation on field, used } 5 \text { spikes, obtained } 34 \text { germinable seeds at } \\
\text { Stende }\end{array}$ \\
\hline 1986 & $\mathrm{~F}_{0}$ & F-86-22 & Donskaya polukarlikovaya/Abe//Lowrin 34 & $\begin{array}{l}\text { Hybridisation on field, used two spikes, and obtained } 12 \text { germinable } \\
\text { seeds at Stende }\end{array}$ \\
\hline 1987 & $\mathrm{~F}_{1}$ & F-86-22 & $-“-$ & Seed multiplication at Stende \\
\hline 1990 & $\mathrm{~F}_{3}$ & F-86-22 & - “- & Seed multiplication at Stende \\
\hline 1992 & $\mathrm{~F}_{4}$ & F-86-22 & $-“-$ & Seed multiplication, and a pure line selection at State Stende CBI \\
\hline 1993 & $\mathrm{~F}_{5}$ & L-93-130 & $-“-$ & Seed multiplication, at Stende $\left(1 \mathrm{~m}^{2}\right)$ \\
\hline 1994 & $\mathrm{~F}_{6}$ & $93-130$ & - “- & Seed multiplication and evaluation at Stende $\left(2 \mathrm{~m}^{2}\right)$ \\
\hline 1995-1997 & $\mathrm{F}_{7}$ & $93-130$ & $-“-$ & Seed multiplication, at Stende, and evaluation $\left(5 \mathrm{~m}^{2}\right)$ \\
\hline $1998-2000$ & $\mathrm{~F}_{8-} \mathrm{F}_{10}$ & $93-130$ & $-“-$ & Seed multiplication, at Stende, and evaluation ( $10 \mathrm{~m}^{2}, 4$ replicatons $)$ \\
\hline 2003-2006 & & $\begin{array}{l}\text { L-93-130 } \\
\text { 'Fredis' }\end{array}$ & - “- & $\begin{array}{l}\text { VCU test in Latvia, } \\
\text { DUS test in Poland }\end{array}$ \\
\hline
\end{tabular}

2007 winter wheat variety 'Fredis' (KVZ-23) is registered in the Latvian Plant Catalogue

2011 winter wheat variety 'Fredis' (Nr.17-6/94) is registered in the Estonian Plant Catalogue

The spring wheat variety 'Uffo' was selected at the State Stende CBI (1992-2004) from the crossing combination (Sigma/Eta) (Table 2). The authors are Vija Strazdina, Maija Ceraukste, Māra Bleidere, Gints Lanka, Zanda Opmane, and Solveiga Maliecka.

The spring wheat variety 'Robijs' was developed at the State Stende Cereal Breeding Institute in collaboration with the Institute of Biology, University of Latvia, in the period

Table 2

DEVELOPMENT SCHEME OF SPRING WHEAT 'UFFO'

\begin{tabular}{|c|c|c|c|c|}
\hline Year & $\begin{array}{l}\text { Gener- } \\
\text { ation }\end{array}$ & $\begin{array}{c}\text { Number of } \\
\text { hybrid }\end{array}$ & Pedigree & Breeding stage and place \\
\hline 1992 & $\mathrm{~F}_{0}$ & F-01-92 & Sigma/Eta & $\begin{array}{l}\text { Hybridisation on field, used } \\
3 \text { spikes, obtained } 12 \\
\text { germinable seeds at Stende }\end{array}$ \\
\hline 1993 & $\mathrm{~F}_{1}$ & F-01-92 & - " - & $\begin{array}{l}\text { Seed multiplication at } \\
\text { Stende }\end{array}$ \\
\hline 1994 & $\mathrm{~F}_{2}$ & F-01-92 & - " - & $\begin{array}{l}\text { Seed multiplication at } \\
\text { Stende }\end{array}$ \\
\hline 1995 & $\mathrm{~F}_{3}$ & F-01-92 & - " - & $\begin{array}{l}\text { Selection of pure line at } \\
\text { Stende }\end{array}$ \\
\hline 1996 & $\mathrm{~F}_{4}$ & $\begin{array}{l}\text { Std. } \\
91-13-31\end{array}$ & - " - & $\begin{array}{l}\text { Seed multiplication and } \\
\text { evaluation }\left(1-2 \mathrm{~m}^{2}\right) \text { at } \\
\text { Stende }\end{array}$ \\
\hline 1997 & $\mathrm{~F}_{5}$ & $\begin{array}{l}\text { Std. } \\
91-13-31\end{array}$ & — & $\begin{array}{l}\text { Seed multiplication and } \\
\text { evaluation }\left(5 \mathrm{~m}^{2}, 3 \text { replica- }\right. \\
\text { tions }) \text { at Stende }\end{array}$ \\
\hline $\begin{array}{l}1998- \\
2004\end{array}$ & $\mathrm{~F}_{6}-\mathrm{F}_{9}$ & $\begin{array}{l}\text { Std. } \\
91-13-31\end{array}$ & $-“-$ & $\begin{array}{l}\text { Seed multiplication and } \\
\text { evaluation }\left(10 \mathrm{~m}^{2}, 4\right. \\
\text { replicatons }) \text { at Stende }\end{array}$ \\
\hline $\begin{array}{l}2005- \\
2007\end{array}$ & & $\begin{array}{l}\text { 'Uffo' (Std. } \\
91-13-31)\end{array}$ & - " - & $\begin{array}{l}\text { VCU test in Latvia } \\
\text { DUS test in Poland }\end{array}$ \\
\hline
\end{tabular}

2008 spring wheat variety 'Uffo' (KVV 13) is registered in the Latvian Plant Cataloque

2009 spring wheat variety 'Uffo' is registered in the Estonian Plant Cataloque from 2000 to 2007. It was obtained from the crossing combination ('Dragon'/'Anninia'//'Fasan') by anther culture (Table 3). The authors are Vija Strazdina, Maija Ceraukste, Dace Grauda, and Isaak Rashal.

Evaluation and characterisation. Trials of winter wheat and spring wheat nurseries were set up at the State Stende

Table 3

DEVELOPMENT SCHEME OF SPRING WHEAT 'ROBIJS'

\begin{tabular}{|c|c|c|c|c|}
\hline Year & $\begin{array}{c}\text { Gener- } \\
\text { ation }\end{array}$ & $\begin{array}{c}\text { Number of } \\
\text { hybrid }\end{array}$ & Pedigree & Breeding stage and place \\
\hline 2000 & $\mathrm{~F}_{1}$ & F-01-79 & Dragon/Aniina & $\begin{array}{l}\text { Hybridisation on field. In re- } \\
\text { sult obtained } 14 \text { germinable } \\
\text { seeds at Stende, }\end{array}$ \\
\hline 2001 & $\mathrm{~F}_{1}$ & F-02-95 & $\begin{array}{l}\text { Dragon/Aniina// } \\
\text { Fasan }\end{array}$ & \\
\hline 2002 & $\mathrm{~F}_{1}$ & F-03-60 & $\begin{array}{l}{[\text { Dragon/Aniina// }} \\
\text { Fasan]/Fasan }\end{array}$ & \\
\hline 2003 & $\mathrm{~F}_{2}$ & $03-06-2-05$ & - " - & $\begin{array}{l}\text { Five seeds were delivered to } \\
\text { Plant Genetic laboratory In- } \\
\text { stitute of Biology Latvian } \\
\text { University for use of DH } \\
\text { methods }\end{array}$ \\
\hline 2004 & $\mathrm{~F}_{3}$ & $03-06-2-05$ & - " - & $\begin{array}{l}\text { DH } 65 \text { seeds were sown in } \\
\text { the field at Stende }\end{array}$ \\
\hline 2005 & $\mathrm{~F}_{4}$ & $03-06-2-05$ & - " - & $\begin{array}{l}\text { Seed multiplication }\left(1-2 \mathrm{~m}^{2}\right) \\
\text { at Stende }\end{array}$ \\
\hline $\begin{array}{l}2006- \\
2007\end{array}$ & $\mathrm{~F}_{5}$ & DH-3 & - “- & $\begin{array}{l}\text { Seed multiplication and eval- } \\
\text { uation }\left(5-10 \mathrm{~m}^{2}\right)\end{array}$ \\
\hline 2008 & $\mathrm{x}$ & DH-3 & - " - & $\begin{array}{l}\text { VCU test in Latvia, } \\
\text { DUS test in Poland }\end{array}$ \\
\hline 2009 & $\mathrm{x}$ & $\begin{array}{l}\text { DH-3 } \\
\text { 'Robijs' }\end{array}$ & - " - & \\
\hline 2010 & $\mathrm{x}$ & 'Robijs' & - " - & \\
\hline
\end{tabular}


Cereal Breeding Institute in plant breeding crop rotation (conventional fields).

The morphological traits of wheat varieties 'Fredis', 'Uffo' and 'Robijs' ( $F_{2}$ to $F_{9}-F_{10}$ ) were tested every year according to the Community Plant Variety Office (CPVO) Technical Protocol TP/003/4 (Nos. 1-25).

The economically important traits - grain yield $\left(\mathrm{t} \mathrm{ha}^{-1}\right)$ and quality, 1000 kernel weight (g), growing period (days), plant height $(\mathrm{cm})$, lodging resistance (1-9), and resistance to diseases (1-9) - were evaluated every year starting from $\mathrm{F}_{5}$ in $5 \mathrm{~m}^{2}$ plots with three replications, and $\mathrm{F}_{6}-\mathrm{F}_{12}$ in 10 $\mathrm{m}^{2}$ plots with four replications.

Among grain quality features, protein content $\left(\mathrm{mg} \mathrm{kg}^{-1}\right)$, gluten content $\left(\mathrm{mg} \mathrm{kg}^{-1}\right)$, Zeleny index $(\mathrm{mL})$, starch content $\left(\mathrm{mg} \mathrm{kg}^{-1}\right)$, and volume weight $\left(\mathrm{g} \mathrm{l}^{-1}\right)$ were determined using a grain analyzer 'Infratec Analyser 1241'. The Falling number was determined by the ICC Standard method 107/1.

Lodging resistance was evaluated before harvest (Zadoks Growing Stage 80-90) using the scale 1-9 (1 is very low).

Winter wheat resistance to snow mould (Fusarium nivale. (FR.) Ces and Typhula itoana (syn. T. incarnata), Typhula idahoensis (syn. T. borealis) was evaluated after thawing of snow and start of the growing period, and winter hardiness at the beginning of wheat plant tillering (Zadoks Growing Stage 20-29).

During the growing period, resistance to leaf diseases (Blumeria graminis f. sp. tritici, Puccinia triticina, Drechslera tritici-repentis was evaluated using the scale 1-9; (1- infection level is very low).

Statistical analyses were performed using software Microsoft Excel.

\section{RESULTS}

Morphological traits. Cereal varieties can be registered in the EU Plant Catalogue only after receiving a positive conclusion that the variety is distinct, uniform and stable (DUS test). Variety technical reports with more than 25 morphological traits describe the plant growth habit, time of emergence, flag leaf and ear glaucosity, awn and scur presence, ear and grain colour and other significant features. Trait parameters of winter wheat 'Fredis' are shown in the Table 4.

Economical values. From 1997 to 2001, grain yield and grain quality, lodging, resistance to diseases, and winter hardiness, which are economically important traits, were evaluated for line L-93-130 ('Fredis') in comparison with the standard variety 'Kosack' in the State Stende Cereal Breeding Institute.

The variety has a short growing period and is one of the earliest varieties registered in the Latvian Plant Catalogue. The vegetation period is by 10 to 12 days shorter in comparison
Table 4

RESULTS OF TECHNICAL EXAMINATION OF WINTER WHEAT VARIETY 'FREDIS'

\begin{tabular}{|c|c|c|c|}
\hline $\begin{array}{c}\text { CPVO } \\
\text { No }\end{array}$ & Characteristics & State of expression & Note \\
\hline 1 & Coleoptile: anthocyanin coloration & $\begin{array}{l}\text { absent or very } \\
\text { weak }\end{array}$ & 1 \\
\hline 2 & Plant: growth habit & semi-erect & 3 \\
\hline 3 & $\begin{array}{l}\text { Plant: frequency of plants with re- } \\
\text { curved flag leaves }\end{array}$ & low & 3 \\
\hline 4 & $\begin{array}{l}\text { Time of ear emergence (first } \\
\text { spikelet visible on } 50 \% \text { of ears) }\end{array}$ & early & 3 \\
\hline 5 & Flag leaf: glaucosity of sheath & weak & 3 \\
\hline 6 & $\begin{array}{l}\text { Flag leaf: glaucosity of blade } \\
\text { (lower side) }\end{array}$ & $\begin{array}{l}\text { absent or very } \\
\text { weak }\end{array}$ & 2 \\
\hline 7 & Ear: glaucosity & absent or weak & 1 \\
\hline 8 & Culm: glaucosity of neck & $\begin{array}{l}\text { absent or very } \\
\text { weak }\end{array}$ & 2 \\
\hline 9 & $\begin{array}{l}\text { Plant: length (stem, ear, awns and } \\
\text { scurs) }\end{array}$ & short to medium & 4 \\
\hline 10 & $\begin{array}{l}\text { Straw: pith in cross section (half- } \\
\text { way between base of ear and stem } \\
\text { node below }\end{array}$ & very thin & 1 \\
\hline 11 & Ear: shape in profile & tapering & 1 \\
\hline 12 & Ear: density & medium & 5 \\
\hline 13 & $\begin{array}{l}\text { Ear: length (excluding awns and } \\
\text { scurs }\end{array}$ & short & 3 \\
\hline 14 & Awns or scurs: presence & awns present & 3 \\
\hline 15 & $\begin{array}{l}\text { Awns or scurs at type of ear: } \\
\text { length }\end{array}$ & long & 7 \\
\hline 16 & Ear: color & white & 1 \\
\hline 17 & $\begin{array}{l}\text { Apical rachis segment: hairiness of } \\
\text { convex surface }\end{array}$ & medium & 5 \\
\hline 18 & Lower glume: shoulder width & narrow & 3 \\
\hline 19 & Lower glume: shoulder shape & sloping & 1 \\
\hline 20 & Lower glume: beak length & long & 7 \\
\hline 21 & Lower glume: beak shape & straight & 1 \\
\hline 22 & $\begin{array}{l}\text { Lower glume: extent of internal } \\
\text { hairs }\end{array}$ & weak & 3 \\
\hline 23 & Grain: colour & red & 2 \\
\hline 24 & Grain: coloration with phenol & dark & 7 \\
\hline 25 & Seasonal type & winter type & 1 \\
\hline
\end{tabular}

with the standard varieties 'Kosack' and 'Olivin'. The variety will be used as a standard in the early variety group in Estonia. Average grain yield from 2008 to 2010 was $6.9 \mathrm{t}$ $\mathrm{ha}^{-1}\left(-0.9 \mathrm{t} \mathrm{ha}^{-1}\right.$ compared to the standard 'Olivin') at the State Stende CBI (Table 5). Yield maximum $8.9 \mathrm{t} \mathrm{ha}^{-1}$ was obtained in 2007. It had short stem $(85-95 \mathrm{~cm})$, good lodging resistance (7-9) and good winter hardiness (7-9).

Grain of winter wheat 'Fredis' is suitable for food. Given provision of sufficient fertiliser during the vegetation period, the protein content is from 128 to $160 \mathrm{mg} \mathrm{kg}^{-1}$, gluten content from 25 to $35 \%$, Zeleny index $47-54 \mathrm{~mL}$, and TGW 47-52.4 g (Table 6). A negative trait is sensitivity to high ear humidity after ripening.

The winter wheat variety 'Fredis' is conformable to a conventional growing system with application of fertiliser and 
Table 5

GRAIN YIELD OF WINTER WHEAT 'FREDIS' AT STATE STENDE CBI, 2008-2010

\begin{tabular}{|c|c|c|c|}
\hline Trait & Year & 'Fredis' & 'Olivin' Standard \\
\hline \multirow[t]{6}{*}{ Grain yield $t$ ha $^{-1}$} & 2008 & 6.7 & 7.5 \\
\hline & 2009 & 7.2 & 7.8 \\
\hline & 2010 & 6.8 & 8.0 \\
\hline & Mean & 6.9 & 7.8 \\
\hline & $x$ & $-0.9 / 88.46$ & $0 / 100.0$ \\
\hline & \multicolumn{3}{|c|}{$\mathrm{RS}_{000}=0.37$} \\
\hline
\end{tabular}

Table 6

GRAIN QUALITY TRAITS OF WINTER WHEAT 'FREDIS' AT STATE STENDE CBI, MEAN VALUES FOR 2008-2010

\begin{tabular}{l|ll}
\hline \multicolumn{1}{c|}{ Traits } & \multicolumn{1}{c}{ 'Fredis' } & \multicolumn{1}{c}{ 'Olivin' Standard } \\
\hline Heading date & 3.06 & 12.06 \\
Plant height, cm & 87 & 94 \\
TGW, g & 47.9 & 45.4 \\
Volume weight, $\mathrm{kg} \mathrm{l}^{-1}$ & 784 & 788 \\
Protein content, $\mathrm{mg} \mathrm{kg}^{-1}$ & 138 & 127 \\
Gluten content, \% & 25.4 & 23.5 \\
Zeleny index, ml & 49.5 & 47.3 \\
Falling number, s & 267 & 316 \\
Starch content, \% & 66.2 & 67.3
\end{tabular}

restriction of weeds. The variety has moderate sensitivity to leaf diseases (Blumeria graminis f.sp. tritici, Puccinia triticina), and is susceptible to Drechslera tritici-repentis and Tilletia caries.

Spring wheat varieties 'Uffo' and 'Robijs' differ in 16 morphological traits (Table 7). The main differences are: frequency of plants with recurved flag leaves: 'Uffo' -4 (low to medium), 'Robijs' — 7 (high); glaucosity of blade (lower side) of flag leaf and ear glaucosity: 'Uffo' -7 (strong), 'Robijs' — 4 (weak to medium); glaucosity of culm neck: 'Uffo' - 7 (strong), 'Robijs' - 5 (medium); plant length: 'Uffo' - 6 (medium to long), 'Robijs' - 3 (short). Morphological traits of the varieties are closely associated with agronomical features. One of these is cross section of straw pith halfway between base of ear and the stem node below. For variety 'Uffo', straw is very thin (1) indicating weak or moderate lodging resistance (3-5). Variety 'Robijs' has intermediate (5) straw, showing higher lodging resistance (5-7).

Grain yield and quality, lodging and resistance to diseases, and also morphological features were evaluated at the State Stende CBI. from 1997 to 2004 for the spring wheat line Std. 91-13-31 ('Uffo') and from 2009-2011 for the spring wheat line DH-3 ('Robijs'), and compared with the standard 'Vinjett'

Table 7

RESULTS OF TECHNICAL EXAMINATION OF SPRING WHEAT VARIETIES 'UFFO' AND 'ROBIJS'

\begin{tabular}{|c|c|c|c|c|}
\hline $\begin{array}{l}\text { CPVO } \\
\text { No }\end{array}$ & Characteristics & State of expression & $\begin{array}{l}\text { Note } \\
\text { 'Uffo' }\end{array}$ & $\begin{array}{l}\text { Note } \\
\text { 'Robijs' }\end{array}$ \\
\hline 1 & Coleoptile: anthocyanin coloration & & 3 (weak) & 1 ( absent or very weak) \\
\hline 2 & Plant: growth habit & intermediate & 5 & 5 \\
\hline 3 & Plant: frequency of plants with recurved flag leaves & & 4 (low to medium) & 7 (high) \\
\hline 4 & Time of ear emergence (first spikelet visible on $50 \%$ of ears) & medium to late & 6 & 7 \\
\hline 5 & Flag leaf: glaucosity of sheath & strong & 7 & 7 \\
\hline 6 & Flag leaf: glaucosity of blade (lower side) & & 7 (strong) & 4 (weak to medium) \\
\hline 7 & Ear: glaucosity & & 7 (strong) & 4 (weak to medium) \\
\hline 8 & Culm: glaucosity of neck & & 7 (strong) & 5 (medium) \\
\hline 9 & Plant: length (stem, ear, awns and scurs) & & 6 (medium to long) & 3 (short) \\
\hline 10 & $\begin{array}{l}\text { Straw: pith in cross section (halfway between base of ear and stem } \\
\text { node below }\end{array}$ & & 1 (very thin) & 5 (medium) \\
\hline 11 & Ear: shape in profile & tapering & 1 & 1 \\
\hline 12 & Ear: density & & 5 (medium) & 3 (lax) \\
\hline 13 & Ear: length (excluding awns and scurs & & 6 (medium to long) & 7 ( long) \\
\hline 14 & Awns or scurs: presence & Scurs present & 2 & 2 \\
\hline 15 & Awns or scurs at type of ear: length & & 7 (long) & 5 (medium) \\
\hline 16 & Ear: colour & white & 1 & 1 \\
\hline 17 & Apical rachis segment: hairiness of convex surface & & 7 (strong) & 3 (weak) \\
\hline 18 & Lower glume: shoulder width & medium & 5 & 5 \\
\hline 19 & Lower glume: shoulder shape & & 5 (straight) & 3(slightly sloping) \\
\hline 20 & Lower glume: beak length & & 5 (medium) & 4 (short to medium) \\
\hline 21 & Lower glume: beak shape & moderately curved & 4 & 5 \\
\hline 22 & Lower glume: extent of internal hairs & weak & 3 & 3 \\
\hline 23 & Grain: colour & red & 2 & 2 \\
\hline 24 & Grain: coloration with phenol & & 3 ( light) & 5 (medium) \\
\hline
\end{tabular}


The spring wheat varieties 'Uffo 'and 'Robijs' are intermediate intensive varieties, suitable for conventional and organic growing systems in the Baltic region. Both varieties have high yield potential. The average grain yield of the variety 'Uffo' was $6.86 \mathrm{t} \mathrm{ha}^{-1}$ and of the variety 'Robijs' $7.31 \mathrm{t} \mathrm{ha}^{-1}$ (Table 8). Maximum yield was obtained for the variety 'Uffo' - $8.9 \mathrm{t} \mathrm{ha}^{-1}$ in 2007, and 'Robijs' - $8.8 \mathrm{t}$ $\mathrm{ha}^{-1}$ in 2009 . The growing period was 3-4 days longer than that of the standard variety 'Vinjett'. Both varieties had moderate resistance to lodging (5 points), mean stem height was $100 \mathrm{~cm}$, resistance to leaf diseases (Blumeria graminis f. sp. tritici, Puccinia triticina) was moderate, and they were susceptible to Drechslera tritici-repentis and Tilletia caries.

The grain quality of spring wheat varieties 'Uffo' and 'Robijs' were found to be suitable for food and feed; TGW was from 39 to $42 \mathrm{~g}$, protein content $12.5-14.0 \%$, gluten content $20-28 \%$, Zeleny index $35-50 \mathrm{ml}$, falling number 350-370 s (Table 9).

\section{DISCUSSION}

Wheat is one of the most important cereals in Latvia cultivated under conventional and organic agricultural systems. In 2010, the total acreage of wheat was about 350000 ha, or $57 \%$ from the total cereal area. The largest part 250000

Table 8

MEAN GRAIN YIELD OF SPRING WHEAT 'UFFO' AND 'ROBIJS' AT STATE STENDE CBI, 2008-2010

\begin{tabular}{l|l|l|l|l}
\hline Traits & Year & $\begin{array}{l}\text { Standard } \\
\text { Vinjett }\end{array}$ & Uffo & Robijs \\
\hline Yield, t ha & 2008 & 7,74 & 8,48 & 8.98 \\
& 2009 & 5.24 & 5.87 & 6.45 \\
& 2010 & 5.65 & 6.23 & 6.50 \\
Mean & 6.21 & 6.86 & 7.31 \\
+-/ SD & $0.0 / 100$ & $+0.65 / 110.5$ & $+1.1 / 117.7$ \\
& \multicolumn{3}{c}{ RS $_{0.05}=0.45$} &
\end{tabular}

Table 9

CHARACTERISTICS OF AGRONOMICAL AND GRAIN QUALITY TRAITS OF SPRING WHEAT VARIETIES AT STENDE PBI; MEANS FOR 2008-2010

\begin{tabular}{lcccccc}
\hline \multicolumn{1}{c}{ Traits } & $\begin{array}{c}\text { Vinjett } \\
\text { standard }\end{array}$ & Uffo & $\begin{array}{c}+ \text { +- Vinjett } \\
\text { standard }\end{array}$ & Robijs & $\begin{array}{c}\text { +/- Vinjett } \\
\text { standard }\end{array}$ \\
\hline Heading date & 26.06 & 30.07 & +4 & 01.07 & +5 \\
Plant height, cm & 98 & 103 & +5 & 102 & +4 \\
Lodging resistance & $5-7$ & $3-5$ & $-1-2$ & 5 & $-1-2$ \\
$\quad(1-9$ points) & & & & & \\
TKW, g & 38.58 & 39.45 & +0.87 & 39.74 & +1.16 \\
Volume weight, g 1 & 740 & 754 & +14 & 785 & +45 \\
Protein content, \% & 14.3 & 13.4 & -0.9 & 13.0 & -1.3 \\
Gluten content, \% & 25.0 & 24.2 & -0.8 & 24.8 & -0.2 \\
Zeleny index, ml & 40.4 & 38.7 & -1.7 & 38.3 & -2.1 \\
Falling number, s & 256 & 378 & +122 & 357 & +101 \\
Starch content, \% & 66.6 & 67.6 & +1.0 & 67.4 & +0.8
\end{tabular}

300000 ha was sown winter wheat. New intensive growing technologies and high-yield varieties of winter and spring wheat, which were developed in Latvia and in the other European countries, have led to increased wheat production in the last 20 years.

In Latvia farmers have a wide choice of high yield intensive-type varieties, created by foreign companies, but these are not always suited to local agroclimatical conditions. In the Baltic region wheat genotypes need resistance to abiotic (winter hardiness) and biotic (diseases) factors, good lodging resistance, and grain quality acceptable for producers (Strazdina, 2000; Strazdina, 2007; Strazdina et al., 2011).

The breeding strategy for winter and spring wheat varieties at the State Stende Cereal Breeding Institute is to involve in hybridisation various genetic resources from different countries. Lines and varieties from Russia, Ukraine, Nordic countries, Facultative and Winter Wheat Observation Nursery (FAWWON) managed by CIMMYT/Ankara, ICARDA (Syria) and Oregon State University, USA, and other countries, were initially tested in field conditions and after evaluation the conformable material was used in crossing programmes (Strazdina, 2008).

The winter wheat variety 'Fredis' was created from the crossing combination ('Donskaya Polukarlikovaya'/'Abe'// 'Lowrin 24'). The parental form 'Donskaya Polukarlikovaya' ('Rusalka'/'Severodonskaya') (Russia) is awned, with short stem $(80-85 \mathrm{~cm})$, and has good winter hardiness earliness and lodging resistance; yield potential is $7-8 \mathrm{t} \mathrm{ha}^{-1}$. In Latvia, the variety 'Donskaja Polukarlikovaya' was one of the most popular winter wheat varieties from 1980 to 2000 .

The parental form winter wheat 'Abe' (USA) was characterised by good winter hardiness, good grain quality (protein content $13-13.5 \%)$, and high yield potential (8-9 t $\left.\mathrm{ha}^{-1}\right)$. The Variety 'Abe' is awnless, length of stem $108 \mathrm{~cm}$, and has moderate resistance to leaf diseases. In the crossing combination, winter wheat 'Lowrin 34' (Romania) was used to achieve high grain quality and yield stability. This variety showed high yield potential $\left(7-8 \mathrm{t} \mathrm{ha}^{-1}\right)$ and good grain quality (protein content - 13.2\%) in trials at Stende from 1984 to 1986.

Winter wheat 'Fredis' showed good winter hardiness, earliness and high grain quality and is one of most favorite wheat varieties sown in Latvia.

Spring wheat is a less popular cereal than winter wheat. The total area of spring wheat sown was on average 50000 ha annually. In recent years (2010-2011) the area of spring wheat has significantly increased (80 000 ha). Seed companies from Europe have provided Latvian farmers with intensive-type foreign spring wheat varieties.

Currently, cereal breeding has developed varieties suitable to the changing agricultural conditions. A focus is given on conventional high input agriculture, based on high consumption of fossil fuels, pesticides and synthetic fertilisers (Wolfe et al., 2008). 
Modern wheat varieties, bred for genetic uniformity and yield in high input industrial farming systems, narrow the genetic base and has resulted in vulnerability to biotic and abiotic stresses, loss of adaptability, and tolerance to diseases. For these reasons, only a few wheat varieties are suitable for growing under organic conditions (Lammmerts van Bueren et al., 2002; Murphy et al., 2007). Lack of varieties adapted to organic conditions is a problem for wheat growers. Organic farmers still largely depend on varieties produced for conventional farming (Strazdina, et al., 2005).

Since 1990, breeding work of spring wheat has resulted in two new Latvian spring wheat varieties 'Uffo' and 'Robijs', which are suitable for growing in both agricultural systems-conventional and organic (Strazdina and Bleidere 2004).

The spring wheat variety 'Uffo' was created using only traditional breeding methods (hybridisation and individual plant selection). The parental form, spring wheat variety 'Sigma' (Czech Republic), has high grain quality and yield 5-6 $\mathrm{t} \mathrm{ha}^{-1}$, and the spring wheat variety 'Eta' (Poland) had high yield level (6-8 $\left.\mathrm{t} \mathrm{ha}^{-1}\right)$ and good lodging resistance. Both varieties are moderately resistant to leaf diseases in Latvian climatic conditions.

The spring wheat variety 'Robijs' was obtained from the crossing combination ('Dragon'/'Anninia'//'Fasan') by anther culture, at the State Stende Cereal Breeding Institute in collaboration with the Institute of Biology, University of Latvia. The use of plant tissue culture methods, especially doubled haploid (DH) technique, was initiated in 2001 in spring wheat breeding programmes at the State Stende Cereal Breeding Institute. The application of DHs has several advantages over traditional breeding methods. Pure lines can be obtained in one generation, which reduces the time needed to develop a new variety by about 3-4 years. Efficient hybrid evaluation for quantitative and economically important traits and selection can be carried out in early breeding stages, and save costs for field experiments (Grauda et al., 2005; Grauda et al., 2010).

The rapidly increasing impact of global climate change will amplify variability in crop performance in all types of farming, and local plant breeding should provide varieties which guarantee successful crop cultivation results in the changing environment.

\section{REFERENCES}

Grauda, D., Keisa, A., Rashal, I. (2005). Obtaining of doubled haploid lines for Latvian barley and wheat breeding programs by anther culture method. In: Plant Breeding Seed Science, IX (pp. 209-216). Annamaa, K. (ed.). Jõgeva: Jõgeva Plant Breeding Institute.

Grauda, D., Lepse, N., Strazdina, V., Kokina, I., Lapiņa, L., Miķelsone, A., Lublinskis, L., Rashal, I. (2010). Obtaining of doubled haploid lines by anther culture method for the Latvian wheat breeding. Agron. Res., 8, $545-553$.

Murphy, K.M., Campbell, K.G., Lyon, S.R., Jones, S.S.( 2007). Evidence of varietal adaptation to organic farming systems. Field Crops Res.,102, 172-177.

Rashal, I. (2002). Latvian Gene Bank of Cultivated Plants: the first steps. In: "Broad Variation and Precise Characterization - Limitation for the Future”. Proceedings of the XVIth EUCARPIA Section Genetic Resources Workshop, 16-20 May, 2001, Poznań, Poland (pp. 81-83). Święcicki, W., Naganowska, B., Wolko, B. (eds.). Poznań.

Strazdina, V. (2000). Winter wheat Breeding Strategies and results in Latvia. In: Collaboration on Plant Breeding in the Baltic Sea Region, July 13-15, Estonia (pp. 13-15). Jogeva.

Strazdina, V., Bleidere, M. (2004). Cereal varieties for organic farming in Latvia. In: Proceedings of the First World Conference on Organic Seed. July 5-7, Rome, Italy (pp.186-187). Rome.

Strazdina, V., Opmane, Z., Bleidere, M., Zute, S. (2005). The results of cereal varieties suitable for organic farming in Latvia. In: NJF Report, Vol. 1. No. 1, NJF-Seminar 369, Alnarp, Sweden, June 15-17 (p. 259).

Strazdina, V. (2007). Wheat genetic resources and utilization in breeding programs in Latvia. In: Proceedings of the International Scientific Conference Plant Breeding: Scientific and practical aspects to mark the 85th anniversary of the National Plant Breeding in Lithuania, 3-5 July, Dotnuva (p. 24).

Strazdina, V. (2008). Evaluation of main traits and their relationships of spring wheat. Latv. J. Agron.(Agronomijas vēstis), No. 11, Jelgava, $154-158$.

Strazdina, V., Belicka, I, Rashal, I., Grauda, D. (2011). History of wheat breeding development in Latvia. In: The World Wheat Book. Vol. 2. A History of Wheat Breeding (pp. 214-238). Bonjean, A.P., Angus, W.J., van Ginkel, M. (eds.). Paris: Lavoisier Publications.

Strazdina, V. (2012). History of wheat breeding in Latvia. In: Proc. Latv. Acad. Sci., Section B, 66(1/2) (this issue).

Wolfe, M.S., Baresel, J.P., Desclaux, D., Goldringer, I., Hoad, S., Kovacs, G., Löschenberger, F., Miedaner, T., Østergard, H., Lammerts van Bueren, E.T. (2008). Developments in breeding cereals for organic agriculture. Euphytica, 163, pp. 323-346.

Received 7 February 2012

\section{JAUNĀS LATVIJĀ IZVEIDOTĀS ZIEMAS UN VASARAS KVIEŠU ŠKIIRNES}

Valsts Stendes graudaugu selekcijas institūtā no 1986. līdz 2002. gadam selekcionētā ziemas kviešu škirne 'Fredis' ('Donskaja Polukarlikovaja'/'Abe'//'Lowrin 24') ir piemērota audzēšanai Baltijas agroklimatiskajos apstākḷos. Tā ir ziemcietīga, agrīna, vidējā graudu raža - $6.0 \mathrm{t} \mathrm{ha}^{-1}$. Graudu kvalitāte ir piemērota pārtikai. Ziemas kviešu šķirne 'Fredis' reǵistrēta Latvijas augu šḳirņu katalogā no 2007. gada, bet Igaunijā — no 2011. gada. Vasaras kviešu škirne 'Uffo' ('Sigma'/'Eta') veidota Valsts Stendes graudaugu selekcijas institūtā no 1992. līdz 2007. gadam. Tā ir vidēji agrīna, vidēji veldres un slimību izturīga, ar graudu ražas potenciālu 6-8 t ha ${ }^{-1}$. Škirne iekḷauta Latvijas Augu šḳirṇu katalogā no 2008. gada, bet Igaunijas Augu šḳirṇu katalogā - no 2009. gada. Valsts Stendes graudaugu selekcijas institūtā sadarb̄̄bā ar Latvijas Universitātes Biolog̣ijas institūtu, izmantojot tradicionālās un biotehnoloǵijas metodes (dubultotie haploîdi), izveidota vasaras kviešu škirne 'Robijs' ('Dragon'/‘Anninia'//'Fasan'//‘Fasan'). Šķirne ir augstražīga (6-8 t ha" ${ }^{-1}$ ), vidēji veldres un slimību izturīga. Latvijas augu šḳirṇu katalogā reǵistrēta no 2011. gada. Vasaras kviešu šķirnes 'Uffo' un 'Robijs' ir piemērotas audzēšanai gan konvencionālajā, tā arī bioloğiskajā lauksaimniecības sistēmā. Graudi ir izmantojami pārtikai vai lopbarībai. 